\title{
sciendo
}

DOI 10.2478/sbe-2020-0016

SBE no. 15(1) 2020

\section{DOES BETTER MANAGEMENT OF FINANCIAL OBLIGATION PROMOTE PRODUCTIVITY?}

\author{
PRATAP SINGH AWADHESH \\ Indian Institute of Management Lucknow, India
}

\begin{abstract}
:
The purpose of this paper is to examine the role of key financial obligation factors on total factor productivity (TFP) for 34 Indian industries for the period 2008-2018 using qualitative and quantitative techniques. Financial obligations are measured by short- and long-term loans, operating expenses and liabilities. The outcome of qualitative techniques does not appear to support the hypothesis that short term and long-term loans, liabilities and operating expenses influence TFP. On the contrary, the evidences arise from quantitative technique appear to suggest that short term loan and operating expenses promote TFP. The study also suggests that complimentaries exist between operating expenses and short-term loan and they together appear to boost productivity.
\end{abstract}

Key words: Total Factor Productivity, Financial Obligations, Operating Expenses, Liabilities

\section{Introduction}

The aim of this paper is to investigate the role of key financial obligation factors on total factor productivity (TFP). To accomplish this goal, my sample data covers panel of 34 Indian industries for 10 years period (2008-2018). TO ascertain the hypothesis, I use twopronged approach. First, I use qualitative techniques to find the patterns. Second, I employ quantitative technique (system GMM) to validate the quantitative findings and then draw recommendations.

From the past one decade, several authors argued about the linkages between productivity and firm's cost management. Shin et al. (2015) used the case of Wal Mart and explained it by using their financial statement that better cost management promotes productivity and profitability simultaneously. Very recently, Gu et al. (2017), Chae et al. (2017) argued that there are various ways to manage financial obligations, and one of which is Information Technology (IT). They further debated that besides reducing manual labour and promoting automation, IT helps to control cost and manage the operating expenses as an enabler. Lu et al. (2018) debated that enabling short term loans and controlling the long-term loans can better manage the financial obligation and that thus 
promotes productivity. In the context of India, Erumban et al. (2016) argued that cost and financial management lead firms to achieve their financial objectives.

To examine the impact of firms' financial obligation on the productivity, I compute operating expense intensity (operating expenses/ total output), short term loan intensity (short term loans/ total output), long term loan intensity (long term loans/ total output) and liability intensity (total liabilities/ total output). Operating expenses represent the charges incurred on enterprise's main operating activities. This is an important variable to explain firm's financial obligation to carry out its core business activities. Short term loans explain that firm needs liquidity to fulfil its short-term financial obligation that is less than 1 year. Higher short loans explain either the firm does not have enough liquid assets or is facing liquidity risk. Long term loans describe firm's long-term financing strategy. Higher leverage or long-term loans explain that firm's interest expenses can overshadow its operating income. It also explains the solvency risk. Liabilities constitute of short- and long-term loan obligations. It also includes contingent provisions that may or may not arise depending on the certain event. Higher liabilities are the first sign of financial distress.

Total factor productivity is computed by advanced productivity estimation technique Wooldridge (2009) which is far better than traditional estimation technique Levinsohn and Petrin (LP, 2003) due to its bootstrapping technique (Ackerberg et al. 2006 and Wooldridge, 2009). LP suffers from collinearity problems because of their two-stage process. The two- stage process represents a flawed sequential fashion to estimate productivity coefficients. The hypothesis about labour is a non-dynamic attribute, is incorrect and therefore, violates the premise to estimate labour in first stage. The labour is always chosen after all the other inputs (i.e. raw material, capital) are determined (Ackerberg et al. 2006).

\section{Data \& Variables}

The study uses data from India's Annual Survey of Industries (ASI). The firm level data covers firms across 34 Indian industries. ASI data comes with firm level unique identifier using which we created a panel for 10 years (2008 to 2018). My sample constitute of 54, 600 plants. Appendix I summarizes the sample industries.

For this study, the data was transformed into Microsoft SQL server 2017 enterprise edition. SQL server is a relational database management product (RDBMS) provided by Microsoft that provides complex programming capabilities. Data was extracted by using two-step technique. First, the data was transferred from text into table format. Second, data series were then formulated by the help of equations given in ASI Tabulation Program.

I treated the data econometrically and removed the missing observations. My sample covers 5,460 firms across 34 industries for the period of 10 years (2008 to 2018). There are two motives to control our panel by econometric treatment. First, this permits the presence of the plant in every year of the panel. Second, in order to avoid losing too many observations in our panel, I limit the panel to include ten years of data, from 2008 to 2018. This shorter time horizon helps as during this time period, India recorded a 
comparatively uniform growth. To treat the missing values in my variables, I use two-step Heckman correction procedure and addressed the possible selection biases.

The data series extracted to carry out the analysis for this paper are: average number of persons worked, net fixed capital stock, depreciation, gross value added (GVA), materials consumed, short term loans, long term loans, operating expenses and total liabilities. To construct panel series like GVA and net fixed capital, I used ASI recommended Tabulation Program and Schedule. Tabulation Program explain the computations to formulate important variables. Schedule explains the information sections which is used to collect the survey information.

The panel series employ in my analysis are deflated with appropriate deflators. The base year is kept as 2008. To compute the capital series, I used the perpetual inventory method recommended by Krishna and Kapila (2009). Following their technique, I used net fixed capital stock at constant prices as the measure of capital inputs as explained below

$$
K \_t=(1-\varphi) K \_(t-1)+G \_t
$$

where $\mathrm{K}$ is the capital stock, $\mathrm{G}$ is the deflated gross investment, $\varphi$ is the rate of depreciation which is taken at $7 \%$ and is inline with the similar studies carried out for India (Mitra et al, 2014) and $t$ indicates the year. Material input series has been deflated by a deflator which is computed as a weighted average of price indices for various input-output sectors. For each industry, WPI (wholesale price indices) have been used (Singh, 2017b). I used the input output table baselined for the year 1993-94 and published by CSO (Central Statistical Organization) for this purpose.

Variables used in this study, their definition, deflators (as applicable) and sources are given in table 1:

Table 1: Variables employed in this study, their deflators and database source

\begin{tabular}{|c|c|c|c|}
\hline Variable & Definition & Deflator & Data Source \\
\hline TFP & Total factor productivity & NA & $\begin{array}{l}\text { Calculated by Wooldridge } \\
\text { technique using GVA, } \\
\text { labour, capital series and } \\
\text { material and fuel } \\
\text { consumed }\end{array}$ \\
\hline $\begin{array}{l}\text { GVA } \\
(\text { INR) }\end{array}$ & $\begin{array}{l}\text { Gross value added (GVA) } \\
\text { of the firm }\end{array}$ & $\begin{array}{l}\text { Deflated by industry } \\
\text { specific wholesale price } \\
\text { indices (WPI) }\end{array}$ & $\begin{array}{l}\text { - GVA obtained from } \\
\text { ASI(EPW) } \\
\text { WPI obtained from the } \\
\text { Ministry of Commerce \& } \\
\text { Industry of India } \\
\text { (http://eaindustry.nic.in) }\end{array}$ \\
\hline $\begin{array}{l}\text { Labour } \\
\text { (INR) }\end{array}$ & $\begin{array}{l}\text { Average number of } \\
\text { persons worked }\end{array}$ & - & - $\quad \mathrm{ASI}(\mathrm{EPW})$ \\
\hline Capital & Fixed capital stock series & Deflator derived from the & Net fixed capital formation \\
\hline
\end{tabular}


Studies in Business and Economics no. 15(1)/2020

\begin{tabular}{|c|c|c|c|}
\hline (INR) & $\begin{array}{l}\text { constructed by perpetual } \\
\text { inventory method }\end{array}$ & $\begin{array}{l}\text { data on gross fixed capital } \\
\text { formation in registered } \\
\text { firms at current and } \\
\text { constants prices given in } \\
\text { NAS }\end{array}$ & $\begin{array}{l}\text { obtained from ASI (EPW) } \\
\text { Deflator obtained from } \\
\text { Macroeconomic } \\
\text { Aggregates } \\
\text { (https://data.gov.in) }\end{array}$ \\
\hline $\begin{array}{l}\text { Operating } \\
\text { Expenses }\end{array}$ & Operating Expenses & $\begin{array}{l}\text { Deflated by industry } \\
\text { specific wholesale price } \\
\text { indices (WPI) }\end{array}$ & ASI (EPW) \\
\hline $\begin{array}{l}\text { Total } \\
\text { Liabilities }\end{array}$ & Total liabilities & $\begin{array}{l}\text { Deflated by industry } \\
\text { specific wholesale price } \\
\text { indices (WPI) }\end{array}$ & ASI (EPW) \\
\hline $\begin{array}{l}\text { Short } \\
\text { Term } \\
\text { debt }\end{array}$ & Short term loans & $\begin{array}{l}\text { Deflated by industry } \\
\text { specific wholesale price } \\
\text { indices (WPI) }\end{array}$ & ASI (EPW) \\
\hline $\begin{array}{l}\text { Long } \\
\text { Term } \\
\text { Loans }\end{array}$ & Long term loans & $\begin{array}{l}\text { Deflated by industry } \\
\text { specific wholesale price } \\
\text { indices (WPI) }\end{array}$ & ASI (EPW) \\
\hline
\end{tabular}

Source: created by author to describe the usage and formulation of variables

\section{TFP Computation and GMM Regression}

To start the analysis, I first compute the TFP for my panel data. I use Wooldridge (2009) production estimation technique. Wooldridge is better than OL and LP techniques as the later ones suffer from collinearity issues due to their flawed two-step process (Ackerberg et al. 2006). The two-step process does not work due to their sequential way to compute productivity coefficients as in this process they fail to deal with serial correlation and heteroskedasticity. Wooldridge technique addresses these issues by employing the bootstrapping process and takes care of the potential issues involved in two-step estimation method by not attempting to identify any production parameters in the first stage.

Table 2 displays the summary statistics of my panel data. The table provides observations and total mean values for total output, labour, intermediate materials (fuel, water charges and material charges), capital, labour, TFP, short term loans, long term loans, operating expenses and liabilities. As many variables in ASI dataset are optional, therefore, number of observations vary across variables reported.

Table 2: Summary statistics of sample data

\begin{tabular}{|c|c|c|c|c|}
\hline Variable & Obs & $\begin{array}{l}\text { Mean (in Million } \\
\text { Rs.) }\end{array}$ & Min (in Million Rs.) & Max (in Million Rs.) \\
\hline Total Output & 54600 & 278000.00 & 6130.00 & 567100000.00 \\
\hline Fuel and Water Charges & 53566 & 761.00 & 0.00 & 3418750.00 \\
\hline Material Charges & 20671 & 7616410.00 & 1.66 & 96718500.00 \\
\hline Intermediate Material & 51227 & 1680040.00 & 0.00 & 33718500.00 \\
\hline Gross Fixed Capital & 51177 & 1600.00 & -1190.00 & 770034.00 \\
\hline Labour & 50892 & 0.91 & 0.00 & 78.34 \\
\hline TFP & 52102 & 13.761 & 8.204 & 13.874 \\
\hline
\end{tabular}


Studies in Business and Economics no. 15(1)/2020

\begin{tabular}{|l|r|r|r|r|}
\hline Short team loans & 40890 & 446199.00 & 0.00 & 76388500.00 \\
\hline Long term loans & 41424 & 6377600.00 & 0.00 & 99881100.00 \\
\hline Total Liabilities & 42988 & 9422000.00 & 00.00 & 11988100.00 \\
\hline Operating Expenses & 51005 & 7144820.00 & 0.00 & 88712100.00 \\
\hline
\end{tabular}

Source: created by author to describe summary statistics

Table 3: Summary statistics illustrating total output, capital, labour and estimated TFP (using Wooldridge technique) across industries

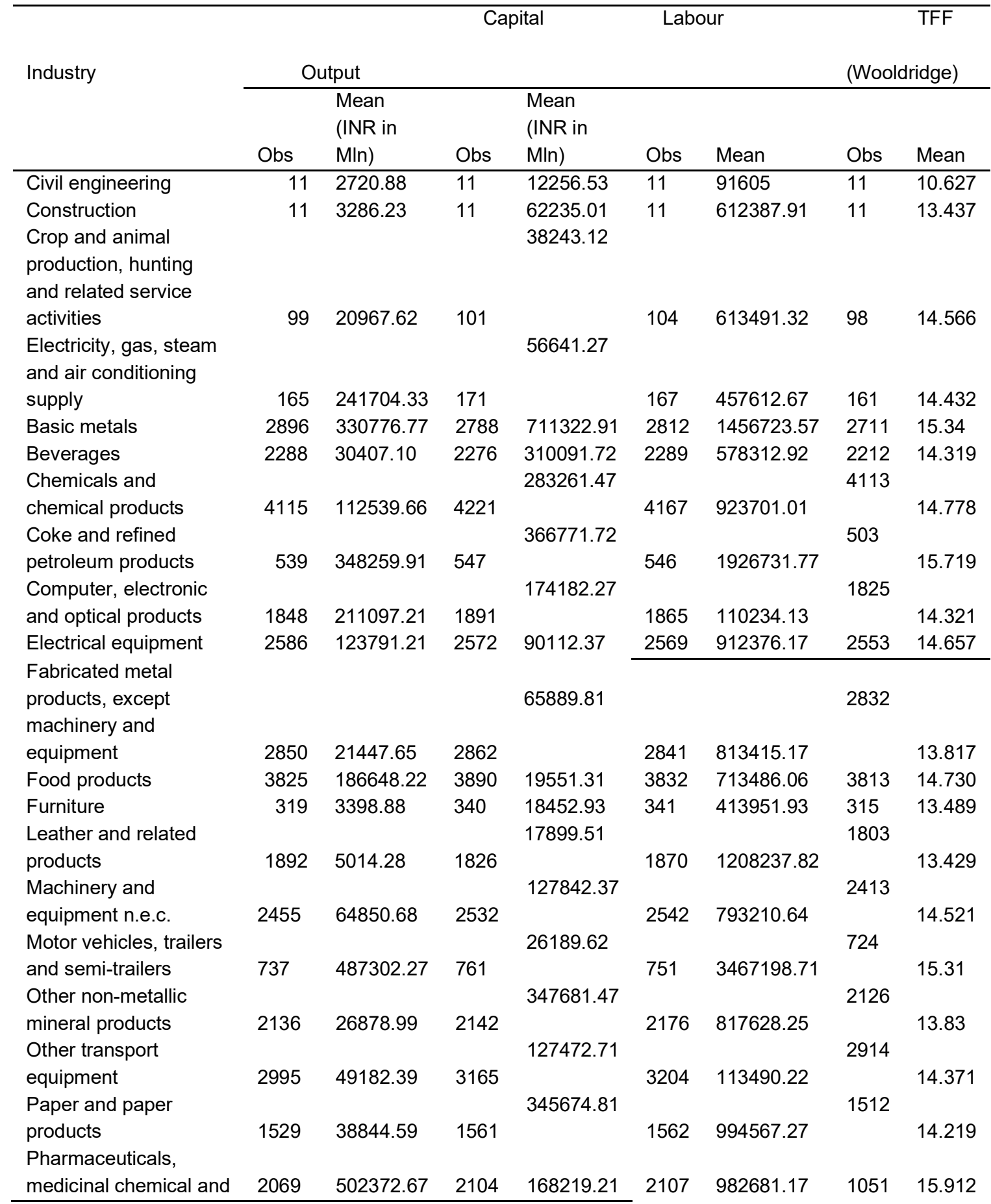




\section{Studies in Business and Economics no. 15(1)/2020}

\begin{tabular}{|c|c|c|c|c|c|c|c|c|}
\hline \\
\hline \multicolumn{4}{|l|}{$\begin{array}{l}\text { Dotanical products } \\
\text { Rubber and plastics }\end{array}$} & \multicolumn{3}{|l|}{162191.57} & \multicolumn{2}{|l|}{2751} \\
\hline products & 2849 & 70505.06 & 2772 & & 2781 & 923761 & & 14.421 \\
\hline Textiles & 2263 & 41244.03 & 2271 & 172301.81 & 2281 & 1784391.38 & 2251 & 14.005 \\
\hline Tobacco products & 341 & 1328.51 & 347 & 3541.91 & 351 & 1986577 & 338 & 11.866 \\
\hline $\begin{array}{l}\text { Wearing apparel } \\
\text { Wood and products of } \\
\text { wood and cork, except } \\
\text { furniture; }\end{array}$ & 2783 & 6147.79 & 2812 & 30671.78 & 2815 & 1471595 & 2754 & 13.041 \\
\hline Articles of straw and & & & & 37871.43 & & & 734 & \\
\hline $\begin{array}{l}\text { plaiting materials } \\
\text { Motion picture, video }\end{array}$ & 748 & 14160.32 & 751 & & 753 & 471954 & & 13.29 \\
\hline $\begin{array}{l}\text { and television } \\
\text { programme production, } \\
\text { sound recording and } \\
\text { music publishing }\end{array}$ & & & & 17402.53 & & & 11 & \\
\hline activities & 11 & 11406.78 & 11 & & 11 & 358519 & & 14.901 \\
\hline Other manufacturing & 1881 & 30570.85 & 1892 & 36781.98 & 1901 & 678361.69 & 1873 & 13.791 \\
\hline Other mining and & & & & 51708.75 & & & 66 & \\
\hline quarrying & 66 & 2845.55 & 68 & & 69 & 372812 & & 13.173 \\
\hline Other personal service & & & & 1734.18 & & & 11 & \\
\hline activities & 11 & 522.70 & 11 & & 11 & 327691 & & 12.817 \\
\hline $\begin{array}{l}\text { Printing and } \\
\text { reproduction of }\end{array}$ & & & & 93782.36 & & & 621 & \\
\hline recorded media & 627 & 19828.68 & 629 & & 634 & 397702 & & 13.73 \\
\hline Publishing activities & 165 & 23994.12 & 171 & 93072.65 & 170 & 479061 & 162 & 14.210 \\
\hline $\begin{array}{l}\text { Repair and installation } \\
\text { of machinery and }\end{array}$ & & & & 37567.03 & & & 183 & \\
\hline equipment & 187 & 16519.47 & 182 & & 189 & 760091 & & 14.319 \\
\hline $\begin{array}{l}\text { Waste collection, } \\
\text { treatment and disposal } \\
\text { activities; materials }\end{array}$ & & & & 7291.76 & & & 33 & \\
\hline recovery & 33 & 5671.18 & 33 & & 33 & 189318 & & 14.501 \\
\hline Water collection, & & & & 723.79 & & & 11 & \\
\hline treatment and supply & 11 & 1431.27 & 11 & & 11 & 21065 & & 13.001 \\
\hline
\end{tabular}

\section{Nexus of Financial Obligations and Productivity}

To investigate the impact of firm's financial obligations on its productivity, I use two-pronged approach. First, I use qualitative techniques (i.e. data visualization) to ascertain relationship between variables explaining financial obligation and TFP. Second, to avoid biases that may creep in due to qualitative methods, I then employ quantitative techniques to validate the findings and ascertain my results.

Figure 1 illustrates the trend over the period of 10 years for total factor productivity, short- and long-term inflation adjusted loans (both shows vertically in Indian Rupees, in billions). Four key observations can be drawn from Figure 1. First, the mean total TFP is more or less constant except for 2018 where it takes a significant dip. Second, when TFP goes down in 2018, the short- and long-term loans go up. Third, short- and long-term loans present the similar traits across the years, for example: they both grow together across the years except 2015 where they go down, however TFP does not appear to change with them. To summarize, this outcome does not show the evidence for hypothesis that higher/ 


\section{Studies in Business and Economics no. 15(1)/2020}

lower short- and long-term loans reduce/ increase the productivity for Indian firms. However, this finding needs to be validated through econometrics techniques in the later sections.

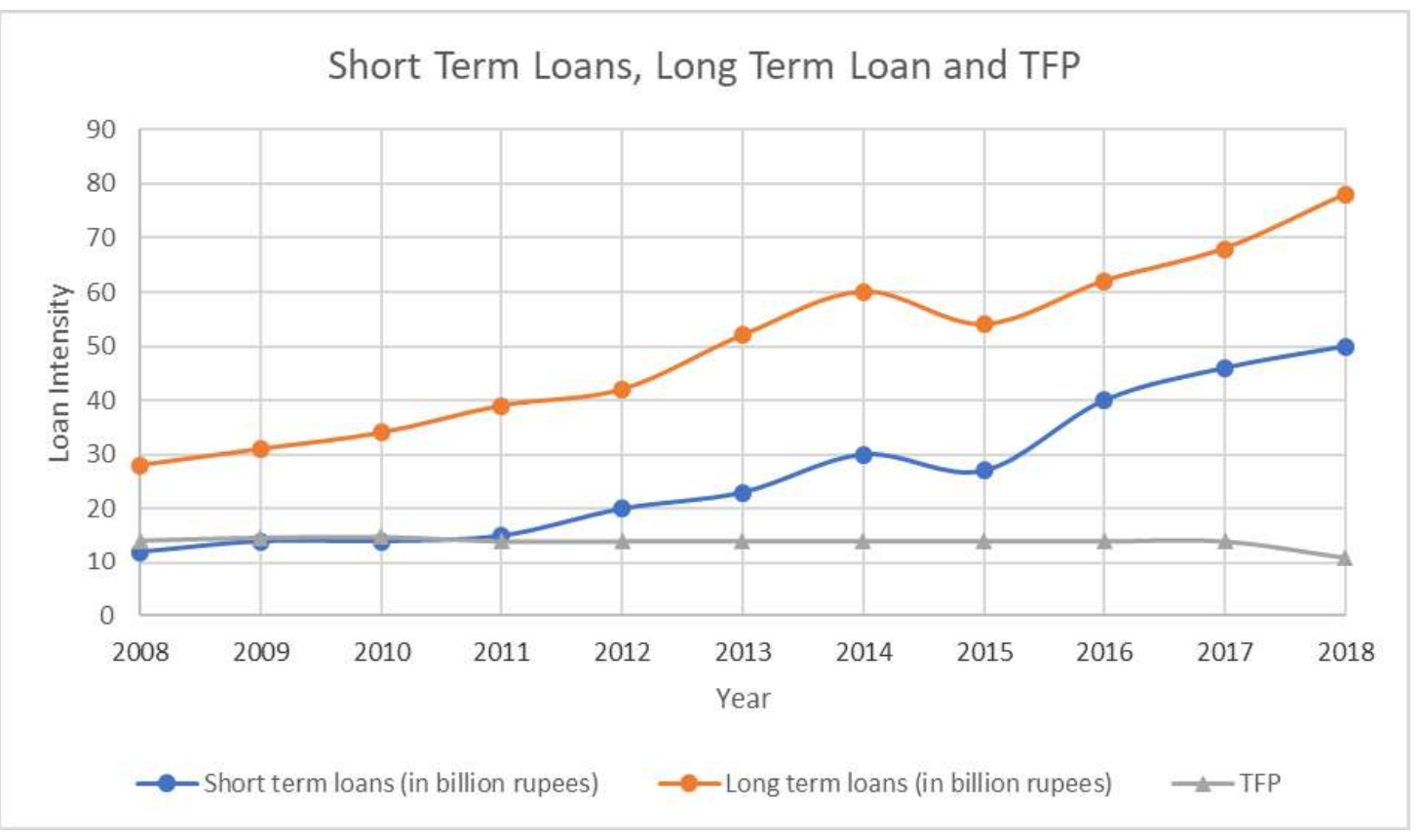

Figure 2 shows the line chart that is drawn between total liabilities and total factor productivity. It is important to note that total liabilities include short term, long term and contingent liabilities. Two key observations are drawn. First, total liabilities go down in 2015 reflecting the similar trend what is observed in figure 1 . This is a well-known fact that 2015 was a bad year for Indian economy and probably this is why reduction in assets by the firms is reflecting the dip in total liabilities (Singh, 2018). Two, total liabilities increase dramatically for three time periods: 2014, 2016 and 2018. Interestingly, productivity does not appear to vary with respect to this change except for 2018. Like in the previous case, I will validate this finding through econometrics techniques in the later sections.

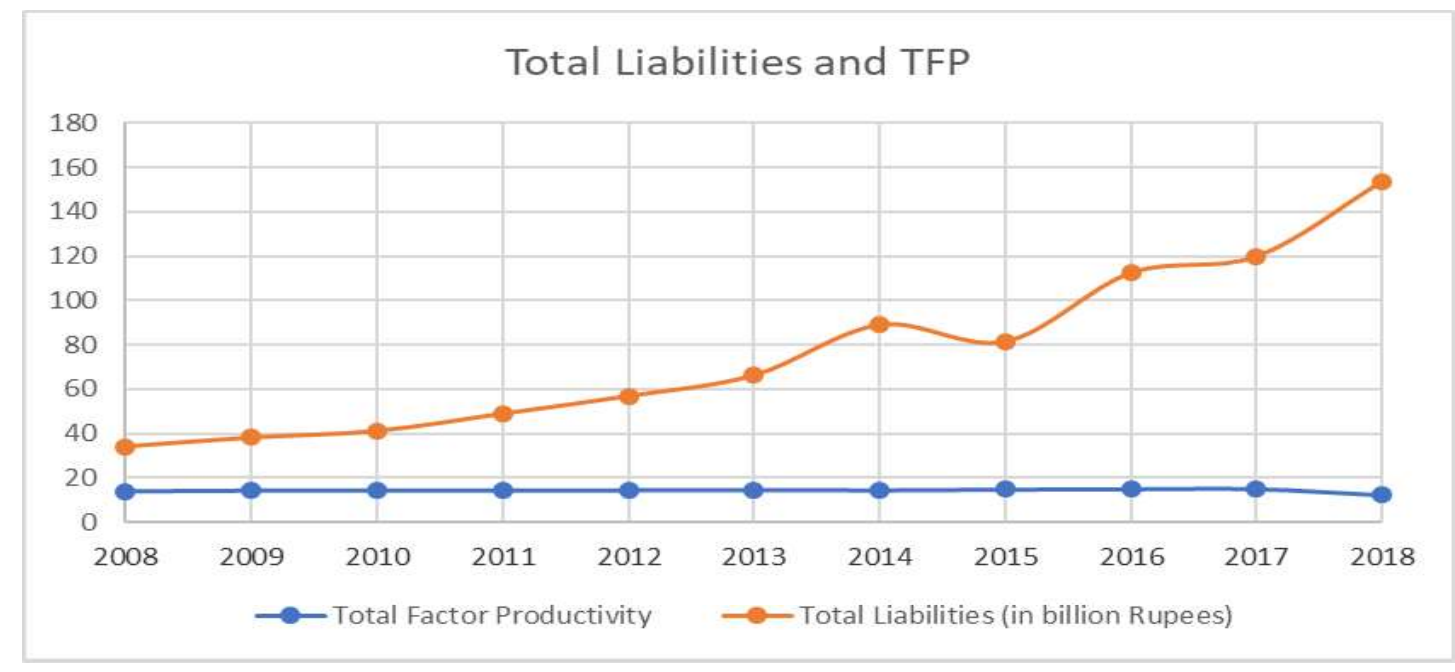


Figure 3 shows the trend between total operating expenses and total factor productivity. Two key observations are drawn from the chart. First, total operating expenses go up consistently across the years though the degree to which it increases in 2012, 2015 and 2016 compared to other years is low. Two, for these years where operating expenses do not grow enough, the TFP does not appear to vary with respect to this change though it goes down in 2018. I will validate these qualitative findings in the subsequent sections by employing econometric techniques.

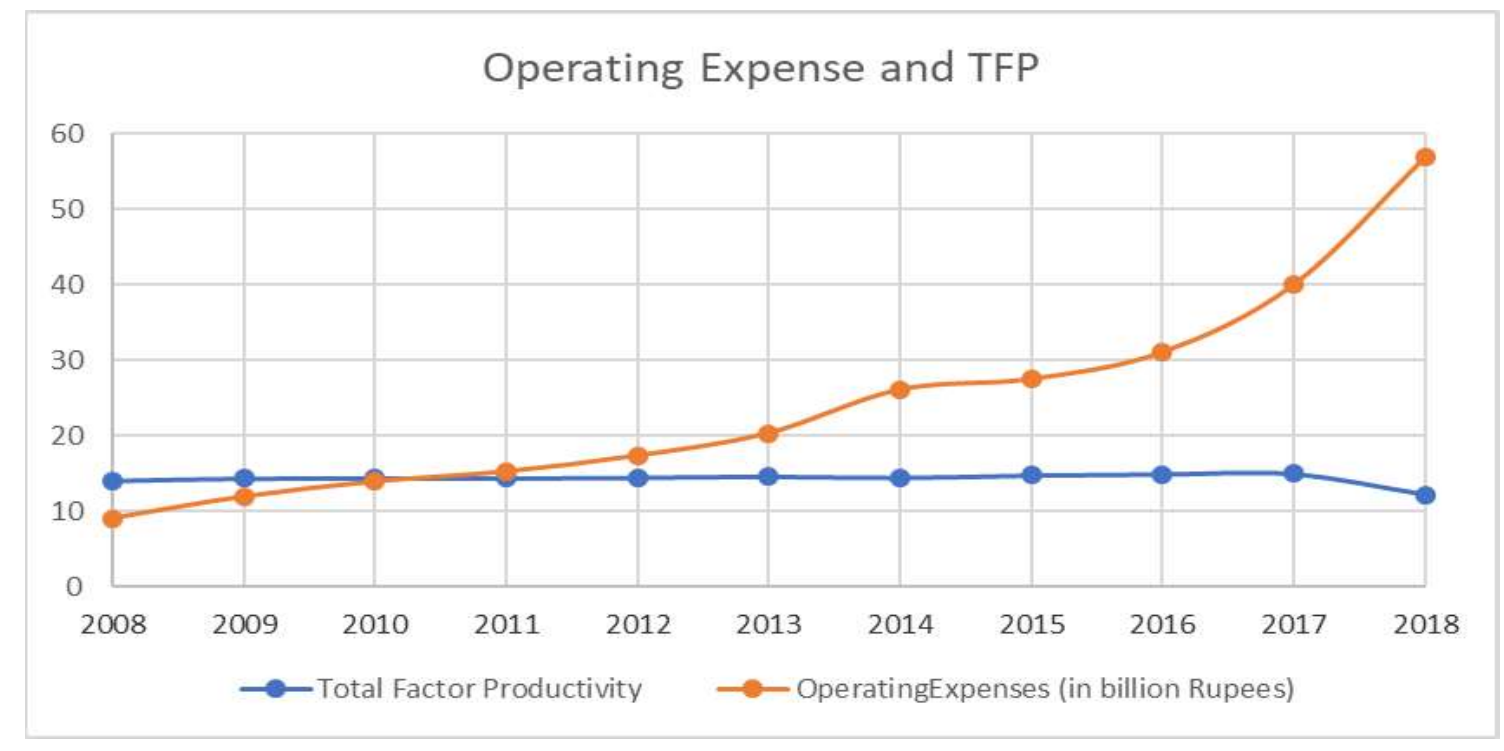

To lay down a foundation of econometrics evidence and to examine the nexus of financial obligation variables and TFP, I carry out regression analyses by employing system GMM methodology. I use this technique as it is broadly acknowledged in the area of productivity and deals with the issue of serial correlation well.

Results of my specification is shown in table 1 . The column 1 specification presents the results of my production function with short term loan intensity, long term loan intensity and liability intensity. Column 2 presents the production function by including liability intensity, operating expenses intensity and the interaction term between the former and the later ones.

Column 3 showcases my production function specification with short term loan intensity, long term loan intensity, liability intensity and two interaction terms, first between short term loan intensity and liability intensity and the second one is between long term loan intensity and liability intensity. Finally, column 4 presents the consolidated production function specification with short- and long-term loan intensity, liability and operating expenses intensity and the four interaction terms that are outlined in column 2 and column 3.

Four key conclusions are drawn from the table. First, short term loan intensity is statistically significant in all three columns 1,3 and 4 and its coefficients are positive. It concludes that short term loans promote productivity. This is probably due to the fact that short term debt is used in working capital to enhance firm's efficiency (Singh, 2017a, 2017b). This, in turn, promotes productivity. Two, long term loan intensity shows significant 
in column 3, however in 1 and 4 it shows insignificant. Overall, it is difficult to reach firm conclusions about the impact of long-term loan intensity on TFP, and therefore, this issue deserves further investigation. Third, liability intensity is statistically insignificant consistently in column 1, 2, 3 and 4 . This explains that liability intensity does not influence productivity. Fourth, operating expenses intensity shows significant in column 2 at $1 \%$ level and column 4 at $10 \%$ level with positive coefficients. This concludes that operating expenses promotes productivity. Fifth, out of 5 interaction terms that are estimated in our specification, only one between operating expenses and short-term loan intensity is significant in column 2 and 4 with $10 \%$ and $1 \%$ level respectively. This indicates complimentaries exist between operating expenses and short-term loan intensity and both of them together appear to boost productivity. This is probably due to the fact that short term loans are used to fund operating expenses and that in turn is used to increase production and thus promote productivity. The other interaction terms formulated in our specification are statistically insignificant.

Table 4: Impact of Short- and Long-Term Loans, Operating Expenses and Liabilities in productivity

\begin{tabular}{|c|c|c|c|c|}
\hline Variable & $\begin{array}{l}\text { GMM } \\
\text { (1) }\end{array}$ & $\begin{array}{l}\text { GMM } \\
(2)\end{array}$ & $\begin{array}{l}\text { GMM } \\
\text { (3) }\end{array}$ & $\begin{array}{l}\text { GMM } \\
\text { (4) }\end{array}$ \\
\hline Capital & $\begin{array}{l}0.418^{\star \star \star} \\
(0.0624)\end{array}$ & $\begin{array}{l}0.388^{* \star \star} \\
(0.236)\end{array}$ & $\begin{array}{l}0.447^{\star \star \star} \\
(0.029)\end{array}$ & $\begin{array}{l}0.526^{* \star *} \\
(0.0227)\end{array}$ \\
\hline IT investments & $\begin{array}{l}0.279^{* * *} \\
(0.055)\end{array}$ & $\begin{array}{l}0.361^{*} \\
(0.278)\end{array}$ & $\begin{array}{l}0.359^{\star} \\
(0.0317)\end{array}$ & $\begin{array}{l}0.368^{*} \\
(0.018)\end{array}$ \\
\hline Workers & $\begin{array}{l}0.117^{* *} \\
(0.0271)\end{array}$ & $\begin{array}{l}0.179^{*} \\
(0.074)\end{array}$ & $\begin{array}{l}0.174^{*} \\
(0.0427)\end{array}$ & $\begin{array}{l}0.119^{*} \\
(0.028)\end{array}$ \\
\hline Short term loan Intensity & $\begin{array}{l}1.081^{*} \\
(.043)\end{array}$ & & $\begin{array}{l}1.0276 \text { ** } \\
(0.0343)\end{array}$ & $\begin{array}{l}1.067^{*} \\
(.0019)\end{array}$ \\
\hline Long term loan intensity & $\begin{array}{l}-0.017 \\
(.0527)\end{array}$ & & $\begin{array}{l}0.021^{*} \\
(.0662)\end{array}$ & $\begin{array}{l}0.219 \\
(0.112)\end{array}$ \\
\hline Liability Intensity & $\begin{array}{l}0.14483 \\
(0.6951)\end{array}$ & $\begin{array}{l}-0.0612 \\
(0.0218)\end{array}$ & $\begin{array}{l}1.072 \\
(.0991)\end{array}$ & -0.672 \\
\hline $\begin{array}{l}\text { Operating Expense } \\
\text { Intensity }\end{array}$ & & $\begin{array}{l}1.00189^{* * *} \\
(0.0306)\end{array}$ & & $\begin{array}{l}1.221^{*} \\
(0.0662)\end{array}$ \\
\hline $\begin{array}{l}\text { Operating Expense } \\
\text { Intensity * Liability Intensity }\end{array}$ & & $\begin{array}{l}-0.8247 \\
(0.0210)\end{array}$ & & $\begin{array}{l}2.874 \\
(1.119)\end{array}$ \\
\hline $\begin{array}{l}\text { Short term loan intensity * } \\
\text { Liability Intensity }\end{array}$ & & & $\begin{array}{l}0.964 \\
(1.47493)\end{array}$ & $\begin{array}{l}-0.855 \\
(0.00)\end{array}$ \\
\hline $\begin{array}{l}\text { Long term loan intensity * } \\
\text { Liability Intensity }\end{array}$ & & & $\begin{array}{l}-0.226 \\
(0.005)\end{array}$ & $\begin{array}{l}0.223 \\
(0.0694)\end{array}$ \\
\hline $\begin{array}{l}\text { Short term loan intensity * } \\
\text { Operating Expense } \\
\text { Intensity }\end{array}$ & & $\begin{array}{l}1.021^{*} \\
(.0662)\end{array}$ & & $\begin{array}{l}1.290^{* * *} \\
(.0085952)\end{array}$ \\
\hline $\begin{array}{l}\text { Long term loan intensity * } \\
\text { Operating Expense } \\
\text { Intensity }\end{array}$ & & $\begin{array}{l}1.072 \\
(.0991)\end{array}$ & & $\begin{array}{l}0.873^{*} \\
(0.004)\end{array}$ \\
\hline
\end{tabular}




\section{Studies in Business and Economics no. 15(1)/2020}

\begin{tabular}{|l|l|l|l|l|}
\hline Constant & $\begin{array}{l}8.487^{* * *} \\
(2.117)\end{array}$ & $\begin{array}{l}11.662^{* * *} \\
(1.009)\end{array}$ & $\begin{array}{l}6.499^{* * *} \\
(3.551)\end{array}$ & $\begin{array}{l}12.872^{* * *} \\
(0.516)\end{array}$ \\
\hline Number of observations & 45620 & 46760 & 45620 & 41570 \\
\hline
\end{tabular}

Source: author calculations from ASI data (2008-2018)

Note: $\quad$ 1. ${ }^{*} p<0.10,{ }^{* *} p<0.05,{ }^{* * *} p<0.01$

\section{Conclusion}

The study investigates the role of key financial obligation factors on TFP for 34 Indian industries for the period 2008-2018 by first employing qualitative techniques and thereafter validates the findings by using quantitative techniques. Financial obligations are defined by four variables, namely, short- and long-term loans, operating expenses and liabilities. The productivity is measured by total factor productivity (TFP).

Qualitative techniques do not yield any evidence to support that short term and long-term loans, liabilities and operating expenses influence TFP. To validate this outcome, quantitative techniques were adopted that provided the evidences that short term loan intensity and operating expenses promote TFP. The specification also suggests that complimentaries exist between operating expenses and short-term loan intensity and both of them appear to boost productivity. Quantitative specification suggests that long term loans and liabilities do not appear to influence productivity.

Two main implications follow from this study. First, while the paper considers 34 diverse Indian industries, however the results cannot be generalized and need further validation with much bigger sample. Second, it is important to verify the findings of this study across industry specific time series and cross section data.

The findings of this paper provide scope for future studies: (I). validating the finding of this study for traditional vs modern industries and draw conclusions (II). Validate the findings of this study across developing, developed and newly industrialized countries and draw comparisons (III). Investigates why long-term loans and liabilities do not boost productivity

\section{References}

Ackerberg, D., Caves, K., \& Frazer, G. (2006). Structural identification of production functions.

Chae, H. C., Koh, C. E., \& Park, K. O. (2018). Information technology capability and firm performance: Role of industry. Information \& Management, 55(5), 525-546.

Erumban, A. A., \& Das, D. K. (2016). Information and communication technology and economic growth in India. Telecommunications Policy, 40(5), 412-431.

Gu, Q., Jitpaipoon, T., \& Yang, J. (2017). The impact of information integration on financial performance: A knowledge-based view. International Journal of Production Economics, 191, 221-232.

Krishna, K. L., \& Kapila, U. (Eds.). (2009). Readings in Indian Agriculture and Industry. Academic Foundation.

Levinsohn, J. and Petrin, A., 2003. Estimating production functions using inputs to control for unobservables. The Review of Economic Studies, 70(2), pp.317-341. 
Lu, Y., Shi, H., Luo, W., \& Liu, B. (2018). Productivity, financial constraints, and firms' global value chain participation: Evidence from China. Economic Modelling.

Mitra, A., Sharma, C., \& Véganzonès-Varoudakis, M. A. (2014). Trade liberalization, technology transfer, and firms' productive performance: The case of Indian manufacturing. Journal of Asian Economics, 33, 1-15.

Olley, G.S. and Pakes, A., 1992. The dynamics of productivity in the telecommunications equipment industry (No. w3977). National Bureau of Economic Research.

Singh, A. P. (2016a). Do Technology Spillovers Accelerate Performance of Firms? Unravelling a Puzzle from Indian Manufacturing Industry. Economics and Applied Informatics, (3), 108-120. Singh, A. P. (2016b). R\&D spillovers \& productivity growth: evidence from Indian manufacturing. Indian Journal of Industrial Relations, 51(4), 563-579.

Singh, A. P. (2017a). Merge or Acquire-A Strategic Framework. Economics and Applied Informatics, (3), 125-139.

Singh, A. P. (2017b). Keeping It Simple: Comparative Analysis of TFP across Manufacturing Industries and Major States of India. Theoretical Economics Letters, 7(06), 1821.

Singh, A. P. (2017c). Does FDI Promote Productivity? A Deep Dive. Indian Journal of Industrial Relations, 52(3).

Singh, A. P. (2018). Does Size Matter?-The Effect of Size of Production Workers, Management Staff and Proprietors on Productivity. Theoretical Economics Letters, 8(11), 2290. Shin, S., \& Eksioglu, B. (2015). An empirical study of RFID productivity in the US retail supply chain. International Journal of Production Economics, 163, 89-96.

Wooldridge, J.M., 2009. On estimating firm-level production functions using proxy variables to control for unobservables. Economics Letters, 104(3), pp.112-114. 